\title{
An Empirical Study of University Education and Graduate Employability in Tanzania
}

\author{
Darlene Mutalemwa
}

\begin{abstract}
Mzumbe University, Dar es Salaam Campus College, P.O.Box 20266, Dar es Salaam, Tanzania. e-mail: dmutalemwa@mzumbe.ac.tz
\end{abstract}

DOI: $10.51865 /$ EITC.2021.04.03

\begin{abstract}
Few would challenge the proposition that employability skills are fundamental for success in the workplace. Yet much evidence suggests the skills mismatch and hiring talent is of great concern to employers around the globe. When it comes to 'hard' data with reference to employability skills in the Tanzanian context, there is a dearth of empirically verifiable statistics from an academic standpoint. The study takes up this challenge to investigate perceptions of 314 graduates on the role of university education in preparing them for the world of employment. Findings have shown a different perspective regarding the quality and employability of Tanzanian graduates. Graduates were appreciative of their university education and were confident that they can meet the requirements of the labour market. However, they acknowledged their theoretical knowledge has little value until they can apply it for practical purposes thus implying their participation in society and ability to cope with changes and recover from problems and challenges brought about by the world of work will be limited. The study urges Tanzania to cautiously devise and execute a plan for developing skills for employability within the education system and ultimately build world class-education systems which will enhance employment prospects for graduates.
\end{abstract}

Keywords: graduate employability skills; university education; innovation; Tanzania.

JEL Classification: I21; I25; I28; O30; O55.

\section{Introduction}

The demands on universities to play a central role through their teaching and research activities in supporting businesses and communities , promoting local and national economic growth and innovation, and supplying highly skilled and employable graduates has been acknowledged by both academicians and practitioners (International Labour Office 2012a; International Labour Office, 2012b; Mkude et al., 2003; Mirondo, 2017;World Bank, 2014). In Tanzania, skills development is one of the most important point of discussion in the Tanzanian National Five Year Development Plan 2016/17-2020/21 (URT, 2016) as the government is seeking to achieve several ambitions by 2025 (URT, 2002). The underlying objective is keeping Tanzania on the path to raising productivity, meeting rapidly changing workforce needs and ensuring everyone can fulfil their potential. 
The education landscape in Tanzania is currently guided by 2016/2017- 2020/21 Education Sector Development Strategy (URT, 2018). Higher education system is divided into nonuniversity level (technical, vocational and professional schools) and university level studies. A student enrols for university after successfully completing A-Level secondary school education (higher secondary), or its technical equivalent. Programmes that range from short-term certificates to doctoral degrees are offered in 43 universities (TCU, 2020). Most bachelor degree courses have a duration of three years except for science degrees specifically pharmacy, nursing, veterinary science and engineering, medicine and law have a duration of 4 years. The Tanzania Commission of Universities (TCU) which regulates the country's university system states that the number of students admitted into bachelor's degree programmes increased progressively from 44,715 in $2012 / 13$, 52,538 in $2013 / 14$, to 59,887 in $2014 / 15$, then 65,105 in 2015/16 and 69,539 in 2016/17 (TCU, 2018).

A total of 286,577 students have graduated from higher learning institutions from 2009/10 to 2016/17 academic years (TCU, 2018). According to the Tanzanian government (URT, 2018: 29) "the number of individuals entering the workforce with a university certification has steadily increased from 1\% in 2007 to $3 \%$ in 2016. Another 214,000 higher education graduates will join the labour market over the coming years, of which $78 \%$ have followed degree courses, $69 \%$ at Bachelor's level and 9\% at postgraduate level or above and $21 \%$ follow non-degree courses. Although the profile of the labour force has a stock of highly qualified graduates, it does not appear to be matched by formal employment opportunities. Highly skilled workforce continues to be low at 3.3\% compared to the required proportion of at least 12\%”.

Scanning through the rich literature on gender, it is apparent that given the strong commitment to promote gender equality, girls still continue to trail behind boys regarding school enrolment, retention, and completion especially in higher learning institutions. The total enrolment in the higher education subsector has remained fairly stable at around 200,000 with only about a third of these being women (URTa, 2018: 13) and just over 2 percent had a completed a tertiary education and only 0.8 percent had a university degree (National Bureau of Statistics, 2017). Gender imbalances in the country are attributed to cultural, social, economic, psychological, historical and political factors (Mori,2014; URT, 2000; URT, 2016).

It is widely observed that the current education and training system does not produce graduates who meet the private sector needs and create their own jobs. The private sector is dominated by (informal) small and medium enterprises and is the leading employer as well as the main engine for future job creation, next only to agriculture. Large enterprises account for only 12 percent of 2.7 million registered enterprises (World Bank, 2014). It is estimated that less than 6 percent of graduates hold public sector wage jobs (Wakkee et al., 2017). In the decades of independence, the state was a default employer of highly educated workers (Simson 2019). Tanzanian, Ugandan and Kenyan graduates' strong preferences for finding future work in the public sector are mainly due to job security and pension benefits. The large share of youth in Tanzanian private sector is explained by the greater employment opportunities in the sector and fewer average years of experience required compared to the public sector (World Bank, 2014).

As part of the government's drive towards spurring private sector driven growth, the introduction of entrepreneurship education in universities has not significantly resulted in an increase in graduates embarking on an entrepreneurial path. This is because entrepreneurship education in the country suffers from rote learning, lack of a more practical approach to entrepreneurial education, and a shortage of knowledge regarding sources of funding and support for people who opt to pursue the entrepreneurship path (Katundu and Gabagambi, 2016; Wakkee et al., 2017). In addition, doing business in Tanzania is also not that easy as evidenced by its dismal ranking of 141 out of 190 countries in the World Bank's Ease of Doing Business Survey for 2020 (World Bank, 2020). The private sector was found to offer a low degree of job protection to youth graduates, who cited the public sector as more job-secure and offering benefits such as pension. 
Regrettably and given the staggering level of unemployment among graduate job-seekers worldwide (ILO, 2020), Tanzania's education system's ethical imperative to deliver knowledge and skills for graduates to be prepared, resourceful and industry aware, have failed to not only to make meaningful change to the ongoing demands of employers but also building the workforce of today and tomorrow for innovation and transformation. Worded differently, graduates do not possess the employability skills required for the labour market (UNIDO and URT, 2012; Mirondo, 2017; Ndyali, 2016; Mwita, 2018; URT ,2016). In order to best prepare overeducated and undereducated graduates entering the labour market for a competitive workplace, this gap or what is often referred to as the war for talent must be addressed.

In the opinion of Policy Forum (2018), a Tanzanian coalition of over 80 not for profit organisations, compulsory and monitored programs to provide practical work and work environment related skills for the youth as soon as they graduate from universities need to be given priority. These programs, which are critical for making the 'unemployable' graduates 'employable' include internship, apprenticeship, graduate placement, residency practicum, monitored graduate volunteer programs, and mentorship. However, close supervision of the government is also needed for the success of these programs. Three years ago, the Government of Tanzania re-affirmed its commitment to improving the quality of higher education and labour market outcomes by launching the National Internship Guidelines (URT, 2017).

There is an expectation among different stakeholders that higher education institutions are mainly responsible for developing the employability of graduates. This article presents a response to the question of whether Tanzanian universities have adequately prepared graduates for employment. It was surprising to discover studies informing the employment agenda for higher education in Tanzania have naively overlooked graduates' experiences, reflections, expectations of teaching, learning and work. Incorporating the authentic feedback of university learners after their transit into the world of work or after they have assumed professional responsibilities should be sought to inform higher education practice and future planning. The study therefore preferred asking graduates to provide their views on the link between education and the world of work as well as the relevance of the curriculum for employability and their confidence in gaining employment. In addition, the study attempts to understand whether graduates respond differently depending on their gender, field of study and employment status.

\section{Theoretical Considerations}

\section{The relationship between education and the world of work}

One of the goals of Tanzania higher education is the acquisition of knowledge, skills, abilities and attitudes essential to become a valuable part of the workforce. In addition, with their unique position within society, universities are also accorded a critical role in the achievement of the United Nations Sustainable Development Goals. The human capital theory (HCT) and credentialism theory paint a positive picture of the benefits of attaining a higher education. Developed in the early 1960s by Gary Becker, HCT asserts that the efficiency of the labour market will allocate the graduates to firms and jobs as required and it assumes that employers are also more willing to pay higher wages to graduates who are better educated and more productive (Becker, 1994). In the credentialism viewpoint (Collin 1979), the purpose of universities is to offer students work readiness credentials i.e. a certificate associated with hard and soft skills for accessing opportunities as a function of the educational investment that they have made. It is also believed that the reputation and prestige of highly rated universities offers better employments prospects through establishing and maintaining contact with employers and alumni than those from low-rated universities (Walker and Fongwa, 2017b; Pitan and Muller, 2019). Both these two theories have not escaped criticisms. Becker's HCT assumes that graduates are in a market economy where there exists perfect competition, perfect market 
information and individuals in such a market are rational. If these were true, there would no skills gap or job-mismatch e.g. no over education or under-education (Dolton et al., 1997) The social capital theory also challenges these theories by postulating that social ties and networks are good predictors for obtaining employment (Coleman, 1990). Sociologists like Bourdieu (1986) argue that hiring of university degree holders is not simply based on an objective evaluation of credentials. Rather the job applicant is assessed based on his or her "fit" with the employer's cultures or worded differently the strategic interest of employers.

Among other issues in the research of transition from higher education to the world of work, an important topic is how university graduates perceive their university degree. One theoretical approach to this subject is the concept of self-perceived employability (Rothwell and Rothwel, 2017). Whilst recognising that there is no universally accepted definition of employability and if employability is defined by Yorke (2006:8) as "a set of achievements - skills, understandings and personal attributes - that makes graduates more likely to gain employment and be successful in their chosen occupations, which benefits themselves, the workforce, the community and the economy", then in this study individual self-perceived employability refers to student's confidence in their own abilities as well as their understanding and awareness of labour market realities, available opportunities in the labour market, the reputation of their university, degree subject and personal factors. In addition, Saher and Ch (2019) explain structural self-perceived employability is about external factors that affect perceptions of graduates such as university reputation, the field of study credibility and demand for the field of study (Paterson, 2017). The study by Al Harti (2011) found that undergraduate students from Egypt and Oman who had not yet experienced the real world of employment, expressed their awareness of the challenges facing them, especially the irrelevance of the courses they take to the skills and competencies they will need on the labour market. This result is consistent with findings from a survey developed by Anderson (2017) which highlights that although Tanzanian graduates were confident that their university education had qualified them to secure employment appropriate to their university education, they, however complained of the lack of applicability of theoretical content taught by the university. Her study also resonates with scholarly studies on Tanzanian graduate employability and curriculum design and syllabi (e.g. Kalufya and Mwakajinga, 2016; Ndyali, 2016; Chuma, 2017; Kamuhabwa, 2017). Tanzanian graduates will not be able to adequately meet the expectations of the world of work when the curriculum does not adequately provide for professional career guidance and counseling services (Chuma, 2017, Policy Forum 2018).

The unemployment of university graduates is affected by a wide range of factors, including economic, social, political and psychological factors (see Brown et al., 2010). Within the literature, there is a general consensus among scholars that explanations for differences and gaps in the employability prospects of graduates can be attributed to specific individual and demographic characteristics. Studies (e.g. Al-Harthi, 2011; Artess et al., 2008; McKnight, 1999; Hanson and Overton 2010a, 2010b, 2010c; Van der Wal Z. and Oosterbaan, 2013, Beaumont et al., 2016; Poon, 2015, Sakar et al., 2016) provide compelling evidence on the likelihood of success in the graduate labour market due to gender and graduates' field of study. On the African continent, male university students in Egypt (Al-Harthi, 2011), South Africa (Monteiro et al., 2016; Qenani et al., 2014) and Tanzania (Dominic and Fulgence, 2019), display greater confidence about graduate employability than female students. In Tanzania, gender equity in higher learning institutions and in technical education is a serious constraint, and more so in the science and technology related academic programmes (URT 2018:17). Significant gender differences provide additional support to psychological theories, stating that males and females have different gender-based perceptions (Venkatesh and Morris, 2000).

Like gender, the field of study is a significant determinant of graduates' labour market outcomes. It is assumed that students choose a particular field because of their expectation to develop professionally in that field. The majority of undergraduate students enrolled in 
Tanzanian universities are enrolled in non-science related courses (Mpehongwaa and Moshi, 2014; URT, 2018). Naong (2011) argues that most South African graduates struggle to find employment because they have chosen the wrong field of study and because of other weaknesses in the national educational system and market. In most OECD countries, graduates from science related degrees are the most employable (OECD, 2017). In Tanzania and South Africa, graduate degree programmes in education offer higher employment prospects than in most other degrees because demand for teachers is always high (Mushi 2013 cited in Kessy 2020; Dunga 2016). In Nigeria, the natural science disciplines are perceived as being of high calibre and having skills required by employers (British Council, 2016).

\section{An alternative explanation: graduate employability for innovation and transformation}

Higher education institutions are often criticized for not preparing graduates for the labour market. This perspective hypothesises that the role of tertiary education systems as centres of innovation in managing the changing environment and responding to advances in technology and globalisation has been unfulfilled and also not been highly valued. A review and evaluation of the performance of Tanzania's higher education institutions in Science, Technology and Innovations (STI) highlights that higher learning institutions wish to become leaders in STI, but for that to happen, a number of quality constraints will need to be overcome (Bastos and Rebois, 2011).

Skills and innovation cannot be discussed in isolation. Despite practitioners and academicians often have differing interpretations of what these two concepts actually entail, the link between skills and innovation has been extensively discussed (OECD, 2011; OECD, 2015, Borrás and Edquist, 2015; Smith et al., 2015; Toner, 2011, World Economic Forum, 2018). Overall, these published studies expose three significant areas of consensus:

Firstly, there are varying definitions of innovation which can change according to place, time, context and disciplines. Innovation is much more about new products, services and processes (operations, organizational structures, business models and relationships) than research and development. Fundamentally innovation is adding value by 'doing new things' and "doing existing things better”, be it in quality or quantity or both. Today, more than ever, universities are expected to increase efficiency, improve the quality and equity of learning opportunities and facilitate graduate employability. These can be achieved by introducing new syllabus, textbooks or education resources, adopting ICT in e-learning services as well as to enhance and redefine relationships with a diverse community of students, staff and employers; and gaining a competitive advantage by deploying new marketing techniques. "Simply put higher education has to change. It needs more innovation” (Wildavsky et al., 2012: 1). Harnessing the benefits of innovation within the education sector itself is fraught with several challenges. In ten European higher education universities, Lašáková et al. (2017) identify the following: the impractical curriculum, the outdated curriculum, lack of investment in technology, poorly-qualified staff, the lack of connection between current teaching and learning practices and the demands of the labour market, employers' expectations and students' needs, to name a few. An almost similar African experience has also been well documented in Nigeria, South Africa, Kenya, Ghana (British Council, 2016) and Tanzania is certainly not an exception (Aubert et al., 2012; Calestous, 2016).

Secondly, innovation requires a wide variety of skills. These include a mixture of technical (also referred as hard skills) and generic skills (also referred as soft skills or non-cognitive skills) which are generated for and applied in the jobs of today and in the future; and in society at large. An OECD (2011) publication devotes extensive space to explain how any shortage or inadequacies of skilled labour or of particular skills and competencies can affect innovation. It cites empirical evidence that demonstrates creating delays to the development of new products and/or creating difficulties in introducing new working practices or technical changes. A skills 
survey by the Government of Tanzania and United Nations for Industrial Organisation (UNIDO) targeting 167 manufacturing businesses in Tanzania revealed that employers were more satisfied with only two soft skills elements (communication and team work skills) and one hard skill element (academic learning) from their university educated workers' and there were still weaknesses in presentation, problem solving, initiative and analytical skills (UNIDO and URT, 2012). Another in-depth survey conducted by a Tanzanian scholar (Mwita, 2018) found that 100 human resources practitioners considered Tanzanian graduates as average on both hard skills (understanding of concepts, breadth of knowledge, application of knowledge, and up-todate) and soft skills (adaptability, attention to detail, commitment, integrity, initiative, selfawareness, punctuality, time management, tolerance to stress, work ethic, cooperation, IT skills, negotiation, problem solving, ethical, communication skills). Mwita (2018: 269) also poignantly notes: "Having graduates who are considered average may trigger unemployment in the country since they will be unwanted by employers but also it may lead to preference of foreign employees to local employees”. Therefore, having graduates who are average is unlikely to result in world changing accomplishments.

The third area of consensus which is also the precise premise of this paper is, a good educational foundation. It is the key to promoting successful innovative practice and ensuring successful transition to the workplace. This critical area should be given priority attention at all levels. Drawing on a review of several studies, Cobo's (2013) rigorous paper on "Skills for innovation: Envisioning An Education that Prepares for Changing World”, explores and discusses key conditions needed to develop skills for innovations within the education system, namely: (i) strengthening the connection and coordination between the world of work and the education sector with the view to improving recognition of the value of graduate skills; (ii) the rapidly changes in the nature of work and the workplace demand universities to build capacities among students and staff for continuous learning, unlearning, and relearning to be competitive globally should not be overlooked; (iii) closely linked to the second condition, using digital technologies to contribute to better application of skills and knowledge in changing unpredictable situations. Technologies are known to be capable of reducing, eliminating jobs and entirely creating new types of jobs and (iv) to survive and thrive in a complex and connected world, soft skills which should be differentiated from academic ability, are increasingly important and complementing hard skills. All these conditions highlight not only the importance of human capital in meeting the goals for innovation, economic growth and living standard but also how and why universities have to prepare their students for success in their first job, future learning, work and life.

\section{Methodology}

The questionnaire was structured in such a way that it has three sections which drew heavily on Al Hardhi's (2011) study. The questionnaire was administered online to graduates who had registered for participation in a soft skills training in Tanzania dubbed Graduates Sales Bootcamp (Mutalemwa, 2020). The response rate of the graduate survey cannot be determined because an open invitation approach was used.

In this study, findings are reported for demographic data of the respondents and 21 employability-oriented opinions also referred as Items (1-21) were solicited from the respondents using a five point Likert scale ranging from 1 (for strongly agree), 2 (agree), 3 (Disagree), 4 (Strongly Disagree ) and to 5 (I don’t know). The data collected in September 2017 was analysed using SPSS software. Means (M) and standard deviations (SD) were used to answer the research questions. A t-test compared graduates' responses according to their gender (males vs. females), their field of study (natural sciences vs social sciences) and employment status (employed versus unemployed). 


\section{Presentation and Analysis of Findings}

Data analysis is based on 314 completely filled in survey forms. The demographic characteristics of the respondents are as follows: In terms of gender, more male respondents (54.8\%) registered for the training than their female counterparts (45.2\%). The students who had registered for the training had completed Bachelor degrees in two fields of study, mainly in social sciences $(86.3 \%)$ followed by natural sciences (13.7\%). In terms of employment status, the majority are unemployed (71.3\%) against $28.7 \%$ who are employed.

Table 1, Table 2 and Table 3 reveal three remarkable findings as follows:

The overall mean in Table 1 indicates that graduates are aware of the crucial link between education and the world of work $(\mathrm{M}=2.46, \mathrm{SD}=1.168)$. This perception corroborates with graduates' perceptions in Egypt (Al-Harti's, 2011) and Tanzania (Anderson, 2017). In this respect, graduates are motivated and have a desire to gain a first degree because they have an interest in a specific field of study at the university that would provide them the skills to meet the requirements of the labour market. The perception held by graduates that they would be in high demand from employers after graduation manifests itself as complacency down the line when they apply for jobs (Table 3).

Table 1. Means and standard deviations for the link between university and the world of work

\begin{tabular}{|c|l|c|c|}
\hline S/N & \multicolumn{1}{|c|}{ Item } & Mean & SD \\
\hline 1 & I've good knowledge about the requirements of future career & 1.59 & 0.766 \\
\hline 2 & I've decided which jobs I'll apply after graduation & 2.3 & 1.283 \\
\hline 3 & I worry a lot about my future career & 3.01 & 1.242 \\
\hline 4 & I must get a job that is appropriate to my academic major & 2.74 & 1.247 \\
\hline 5 & I see a link between academic excellence and my future work success & 2.03 & 1.087 \\
\hline 6 & I chose my field of study because of its strong link to the labour market & 2.25 & 1.197 \\
\hline 7 & $\begin{array}{l}\text { There should be no link between education and the requirements of the labour } \\
\text { market }\end{array}$ & 3.13 & 1.14 \\
\hline 8 & $\begin{array}{l}\text { My love for learning was the reason I enrolled at the university and not to seek a } \\
\text { future job. }\end{array}$ & 2.68 & 1.389 \\
\hline \multicolumn{1}{|c|}{ Overall Mean } & 2.46 & 1.168 \\
\hline
\end{tabular}

Source: Graduate Sales Bootcamp, 2017.

The overall mean in Table 2 suggests that graduates have confidence in securing graduate employment $(\mathrm{M}=2.43$, SD 1.1347). This finding broadly supports the work of other studies such as Al-Harthi (2011), Anderson (2017) and Beaumont et al.. (2016). An interesting perspective from Beaumont et al. (2016: 6) is "confidence [a soft skill] has aspects of both, being a trait that individuals possess, but which may be situationally modified, so that in different circumstances an individual may feel more or less confident”. In short, these studies warn that holding academic qualifications and having confidence does not signify that a student is fully prepared for the world of work.

An important remark that needs to be made from Table 2 is about graduates disagreeing with Item 9 -I prefer to work in the public sector rather than in the private sector $(\mathrm{M}=3.25$; $\mathrm{SD}=$ 1.394) and agreeing with Item 16 - The Government has to provide me with a job appropriate to my university education $(\mathrm{M}=2.76, \mathrm{SD}=1.275)$. These two findings warrant a more detailed discussion which is as follows:

Firstly, Van der Wal and Oosterbaan (2013) claim that the preference for employment in either the public or the private sector can be understood through the lens of value orientations (individual work values vs. organizational values), motivations (intrinsic vs. extrinsic), sector perceptions (positive /negative) and various socialization factors (parental employment, religion, political ideology. Secondly, if graduates are not recruited by the government, then they are likely to have a job in the private sector. After all it is businesses that create jobs and 
not the government. Most private sector jobs can be found in the informal sector with low pay and incentive systems compared to the public sector which has low risk of dismissal and high job security - often in combination with relatively low demands in terms of productivity. A related point is, "the economy [Tanzania], however, is not creating that number of 'good' jobs jobs that pay living wages, give some security of employment, and offer prospects to develop skills” (Page, 2016: 3 citing World Bank 2014). Thirdly, Wakkee et al. (2017: 83) suggests in Tanzania "approximately 40,000 graduates out of 700,000 graduates who enter the labour market annually are hired by the government or established companies despite this being their preferred place of work. The rest of them continue their education, find a low-profiled temporary job or enter into the informal sector". Fourthly, self-employment which is valued by Tanzanian graduates is hampered by several start up barriers including limited business experience and financial and social capital (Katundu and Gabagambi, 2016; Wakkee et al., 2017). Lastly, graduates expect the Tanzanian government through its Ministry of Education in collaboration with the whole government as well as other stakeholders to take action with a shared purpose and implement systemic changes to prepare students for the jobs of today and the future. Restructuring of government functions, privatization and cuts in personnel spending have in East African countries led to a decreased number of public employees (Simson, 2016).

Table 2. Means and standard deviations for the confidence in university education

\begin{tabular}{|c|l|c|c|}
\hline S/N & \multicolumn{1}{|c|}{ Item } & Mean & SD \\
\hline 9 & I prefer to work in the public sector rather than in the private sector & 3.25 & 1.394 \\
\hline 10 & My University education qualifies me to pursue any future work & 1.89 & 1.024 \\
\hline 11 & I'm frightened that my university education has no value on the labour market & 3.45 & 0.875 \\
\hline 12 & $\begin{array}{l}\text { My university education provided offers me opportunities to compete for jobs } \\
\text { even outside my country }\end{array}$ & 1.88 & 1.049 \\
\hline 13 & I trust that I will quickly find a Job appropriate to my university education. & 2.36 & 1.33 \\
\hline 14 & $\begin{array}{l}\text { My university education offers me opportunities to compete for jobs outside of } \\
\text { Tanzania }\end{array}$ & 1.98 & 1.062 \\
\hline 15 & My university education qualifies me to work immediately after graduation. & 2.21 & 1.227 \\
\hline \multicolumn{2}{|c|}{ Overall Mean } & 2.43 & 1.137 \\
\hline
\end{tabular}

Source: Graduate Sales Bootcamp, 2017.

Table 3 shows that graduates are less satisfied with the university curriculum $(\mathrm{M}=2.16, \mathrm{SD}=$ 1.099). This finding is consistent with various Tanzanian-based studies (Anderson, 2017; Chuma, 2017; Kamuhabwa, 2017; Kalufya and Mwakajinga, 2016; Ndyali, 2016) about the quality of the curriculum which is not relevant to the needs of employers.

Table 3. Means and standard deviations for the relevance of curriculum for the world of work

\begin{tabular}{|c|l|c|c|}
\hline S/N & \multicolumn{1}{|c|}{ Item } & Mean & SD \\
\hline 16 & $\begin{array}{l}\text { The government has to provide me with a job appropriate to my university } \\
\text { education. }\end{array}$ & 2.76 & 1.275 \\
\hline 17 & I have to get intensive training after graduation. & 2.38 & 1.303 \\
\hline 18 & $\begin{array}{l}\text { There is no stronger relationship between what we study and the requirement } \\
\text { of the labour market. }\end{array}$ & 2.83 & 1.182 \\
\hline 19 & $\begin{array}{l}\text { The curriculums should include more practical aspect that will better fit our } \\
\text { future careers. }\end{array}$ & 1.38 & 0.715 \\
\hline 20 & $\begin{array}{l}\text { We lack many of the skills we need for our future and current careers, even } \\
\text { after university education. }\end{array}$ & 2.09 & 1.142 \\
\hline 21 & The Curriculums should focus more on generic skills rather than content & 1.57 & 0.978 \\
\hline \multicolumn{2}{|c|}{ Overall Mean } & 2.16 & 1.099 \\
\hline
\end{tabular}

Source: Graduate Sales Bootcamp, 2017. 


\section{Examining the Perception of Graduates in Terms of Gender, Field of Study and Employment Status}

There are several statistical glaring differences in the mean perceptions of the respondents in terms of gender, field of study and employment status. These are elaborated below:

Of the 21 items analysed for gender differences (Table 4, Table 5 and Table 6) only two items achieved statistical significance $(\mathrm{p}<0.05)$. Male graduates had less doubt about the link compared with females for Item 7 in Table 4- There should be no link between education and the requirement of the labour. They were also more confident compared to their counterparts for Item 15 in Table 5-My university education qualifies me to work immediately after graduation. The difference in perception and confidence is related to the most influential demographic characteristics on graduate employability which is gender (Artess et al., 2008; McKnight, 1999). The rich literature on the topic as reported in Poon (2016) and the Tanzanian Education Sector Development Strategy (URT, 2018) indicates barriers that make it more difficult for women to join the workforce can be categorized as person cantered barriers (e.g. skills, knowledge and competencies that are contrary to the demands of the job) and situation centred barriers (e.g. located within work, the political, legal and social cultural environment)

Table 4. Gender differences and the link between university and the world of work

\begin{tabular}{|c|c|c|c|c|c|c|}
\hline $\mathrm{S} / \mathbf{N}$ & Perception & Gender & $\mathbf{N}$ & Mean & SD & Sig. \\
\hline \multirow{2}{*}{1} & \multirow{2}{*}{$\begin{array}{l}\text { I've good knowledge about the requirements of } \\
\text { future career. }\end{array}$} & Male & 172 & 1.56 & .750 & \multirow{2}{*}{.281} \\
\hline & & Female & 142 & 1.63 & .786 & \\
\hline \multirow{2}{*}{2} & \multirow{2}{*}{$\begin{array}{l}\text { I’ve decided which jobs I'll apply after } \\
\text { graduation. }\end{array}$} & Male & 172 & 2.28 & 1.273 & \multirow{2}{*}{.391} \\
\hline & & Female & 142 & 2.31 & 1.300 & \\
\hline \multirow{2}{*}{3} & \multirow{2}{*}{ I Worry a lot about my future career. } & Male & 172 & 3.05 & 1.232 & \multirow{2}{*}{.171} \\
\hline & & Female & 142 & 2.96 & 1.257 & \\
\hline \multirow{2}{*}{4} & \multirow{2}{*}{$\begin{array}{l}\text { I must get a job that is appropriate to my } \\
\text { academic major. }\end{array}$} & Male & 172 & 2.76 & 1.255 & \multirow{2}{*}{.848} \\
\hline & & Female & 142 & 2.70 & 1.242 & \\
\hline \multirow{2}{*}{5} & \multirow{2}{*}{$\begin{array}{l}\text { I see a link between academic excellence and my } \\
\text { future work success. }\end{array}$} & Male & 172 & 2.11 & 1.100 & \multirow{2}{*}{.843} \\
\hline & & Female & 142 & 1.92 & 1.066 & \\
\hline \multirow{2}{*}{6} & \multirow{2}{*}{$\begin{array}{l}\text { I chose my field of study because of its strong } \\
\text { link to the labour market. }\end{array}$} & Male & 172 & 2.27 & 1.140 & \multirow{2}{*}{.800} \\
\hline & & Female & 142 & 2.21 & 1.265 & \\
\hline \multirow{2}{*}{7} & \multirow{2}{*}{$\begin{array}{l}\text { There should be no link between education and } \\
\text { the requirements of the labour market. }\end{array}$} & Male & 172 & 3.09 & 1.115 & \multirow{2}{*}{.040} \\
\hline & & Female & 142 & 3.17 & 1.173 & \\
\hline \multirow{2}{*}{8} & \multirow{2}{*}{$\begin{array}{l}\text { My love for learning was the reason I enrolled at } \\
\text { the university and not to seek a future job. }\end{array}$} & Male & 172 & 2.73 & 1.447 & .590 \\
\hline & & Female & 142 & 2.63 & 1.318 & \\
\hline
\end{tabular}

Source: Graduate Sales Bootcamp, 2017.

Table 5. Gender differences and the confidence in university education

\begin{tabular}{|c|c|c|c|c|c|c|}
\hline $\mathbf{S} / \mathbf{N}$ & Perception & Gender & $\mathbf{N}$ & Mean & SD & Sig. \\
\hline \multirow{2}{*}{9} & \multirow{2}{*}{$\begin{array}{l}\text { I prefer to work in the public sector rather than } \\
\text { in the private sector. }\end{array}$} & Male & 172 & 3.34 & 1.387 & \multirow{2}{*}{.588} \\
\hline & & Female & 142 & 3.13 & 1.398 & \\
\hline \multirow{2}{*}{10} & \multirow{2}{*}{$\begin{array}{l}\text { My University education qualifies me to pursue } \\
\text { any future work. }\end{array}$} & Male & 172 & 1.91 & 1.042 & \multirow{2}{*}{.983} \\
\hline & & Female & 142 & 1.87 & 1.005 & \\
\hline \multirow{2}{*}{11} & \multirow{2}{*}{$\begin{array}{l}\text { I am frightened that my university education has } \\
\text { no value on the labour market. }\end{array}$} & Male & 172 & 3.44 & .887 & \multirow{2}{*}{.087} \\
\hline & & Female & 142 & 3.46 & .864 & \\
\hline \multirow[b]{2}{*}{12} & \multirow{2}{*}{$\begin{array}{l}\text { My university education provided offers me } \\
\text { opportunities to compete for jobs even outside } \\
\text { my country. }\end{array}$} & Male & 172 & 1.91 & 1.048 & \multirow[b]{2}{*}{.312} \\
\hline & & Female & 142 & 1.85 & 1.054 & \\
\hline \multirow{2}{*}{13} & \multirow{2}{*}{$\begin{array}{l}\text { I trust that I will quickly find a Job appropriate } \\
\text { to my university education }\end{array}$} & Male & 172 & 2.41 & 1.346 & \multirow{2}{*}{.476} \\
\hline & & Female & 142 & 2.29 & 1.313 & \\
\hline
\end{tabular}


Table 5 (cont.)

\begin{tabular}{|c|l|l|l|l|l|l|}
\hline \multirow{2}{*}{14} & My university education offers me opportunities & Male & 172 & 2.02 & 1.070 & \multirow{2}{*}{.210} \\
\cline { 3 - 6 } & to compete for jobs outside of Tanzania. & Female & 142 & 1.92 & 1.052 & \\
\hline \multirow{2}{*}{15} & $\begin{array}{l}\text { My university education qualifies me to work } \\
\text { immediately after graduation. }\end{array}$ & Male & 172 & 2.27 & 1.256 & \multirow{2}{*}{.015} \\
\cline { 3 - 5 } & Female & 142 & 2.13 & 1.192 & \\
\hline
\end{tabular}

Source: Graduate Sales Bootcamp, 2017.

Table 6. Gender differences and the relevance of curriculum for the world of work

\begin{tabular}{|c|c|c|c|c|c|c|}
\hline $\mathbf{S} / \mathbf{N}$ & Perception & Gender & $\mathbf{N}$ & Mean & SD & Sig. \\
\hline \multirow{2}{*}{16} & \multirow{2}{*}{$\begin{array}{l}\text { The government has to provide me with a job } \\
\text { appropriate to my university education. }\end{array}$} & Male & 172 & 2.82 & 1.274 & \multirow{2}{*}{.425} \\
\hline & & Female & 142 & 2.70 & 1.277 & \\
\hline \multirow{2}{*}{17} & \multirow{2}{*}{ I have to get intensive training after graduation. } & Male & 172 & 2.50 & 1.268 & \multirow{2}{*}{.320} \\
\hline & & Female & 142 & 2.23 & 1.334 & \\
\hline \multirow[b]{2}{*}{18} & \multirow{2}{*}{$\begin{array}{l}\text { There is no stronger relationship between what } \\
\text { we study and the requirement of the labour } \\
\text { market }\end{array}$} & Male & 172 & 2.80 & 1.193 & \multirow[b]{2}{*}{.226} \\
\hline & & Female & 142 & 2.87 & 1.172 & \\
\hline \multirow{2}{*}{19} & \multirow{2}{*}{$\begin{array}{l}\text { The curriculums should include more practical } \\
\text { aspect that will better fit our future careers. }\end{array}$} & Male & 172 & 1.43 & .765 & \multirow{2}{*}{.290} \\
\hline & & Female & 142 & 1.32 & .647 & \\
\hline \multirow[b]{2}{*}{20} & \multirow{2}{*}{$\begin{array}{l}\text { We lack many of the skills we need for our } \\
\text { future and current careers, even after university } \\
\text { education. }\end{array}$} & Male & 172 & 2.19 & 1.170 & \multirow{2}{*}{.214} \\
\hline & & Female & 142 & 1.98 & 1.101 & \\
\hline \multirow{2}{*}{21} & \multirow{2}{*}{$\begin{array}{l}\text { The curriculum should focus more on generic } \\
\text { skills rather than content. }\end{array}$} & Male & 172 & 1.56 & .980 & \multirow{2}{*}{.425} \\
\hline & & Female & 142 & 1.57 & .978 & \\
\hline
\end{tabular}

Source: Graduate Sales Bootcamp, 2017.

Table 7 Table 8 and Table 9 display results for differences in means for field of study between natural sciences graduates and social sciences graduates. Only two items out of 21 were statistically significant $(\mathrm{p}<0.05)$. Graduates with an academic background in natural sciences complained less compared to social sciences graduates about Item 19 and 21 in Table 9: The curriculum should include more practical aspect that will better fit our future careers and the curriculum should focus more on generic skills in the curriculum rather than content. The findings suggest that compared to social science graduates, sciences graduates perceive less Tanzanian educational institutions to lack instructional capacity to develop and deliver relevant up-to-date competency-based training. Although, there has been a small but increasing trend in science related courses in Tanzania (URT, 2018) which is still insufficient to meet the needs of the economy, the evidence from African countries (British Council, 2016) suggests that graduates from sciences related field generally find employment more easily compared to graduates from other fields. The large proportion of Tanzanian enrolment concentrated in nonscience-related fields (URT, 2018) contributes to a situation in which many graduates are unemployed following the completion of their studies.

Table 7. Field of study differences and the link between university and the world of work

\begin{tabular}{|c|c|c|c|c|c|c|}
\hline $\mathbf{S} / \mathbf{N}$ & Perception & $\begin{array}{l}\text { Academic } \\
\text { Profession }\end{array}$ & $\mathbf{N}$ & Mean & SD & $\begin{array}{l}\text { Sig. (2- } \\
\text { tailed) }\end{array}$ \\
\hline \multirow{2}{*}{1} & \multirow{2}{*}{$\begin{array}{l}\text { I've good knowledge about the } \\
\text { requirements of future career. }\end{array}$} & Natural Science & 43 & 1.53 & .735 & \multirow{2}{*}{.597} \\
\hline & & Social Science & 271 & 1.60 & .772 & \\
\hline \multirow{2}{*}{2} & \multirow{2}{*}{$\begin{array}{l}\text { I've decided which jobs I'll apply } \\
\text { after graduation. }\end{array}$} & Natural Science & 43 & 2.21 & 1.166 & \multirow{2}{*}{.634} \\
\hline & & Social Science & 271 & 2.31 & 1.302 & \\
\hline \multirow{2}{*}{3} & \multirow{2}{*}{$\begin{array}{l}\text { I Worry a lot about my future } \\
\text { career. }\end{array}$} & Natural Science & 43 & 2.70 & 1.245 & \multirow{2}{*}{.076} \\
\hline & & Social Science & 271 & 3.06 & 1.237 & \\
\hline \multirow{2}{*}{4} & \multirow{2}{*}{$\begin{array}{l}\text { I must get a job that is appropriate } \\
\text { to my academic major. }\end{array}$} & Natural Science & 43 & 2.81 & 1.180 & \multirow{2}{*}{.659} \\
\hline & & Social Science & 271 & 2.72 & 1.259 & \\
\hline
\end{tabular}


Table 7 (cont.)

\begin{tabular}{|c|c|c|c|c|c|c|}
\hline \multirow{2}{*}{5} & \multirow{2}{*}{$\begin{array}{l}\text { I see a link between academic } \\
\text { excellence and my future work } \\
\text { success. }\end{array}$} & Natural Science & 43 & 2.00 & 1.134 & \multirow{2}{*}{.869} \\
\hline & & Social Science & 271 & 2.03 & 1.081 & \\
\hline \multirow[b]{2}{*}{6} & \multirow{2}{*}{$\begin{array}{l}\text { I chose my field of study because } \\
\text { of its strong link to the labour } \\
\text { market. }\end{array}$} & Natural Science & 43 & 2.40 & 1.178 & \multirow[b]{2}{*}{.377} \\
\hline & & Social Science & 271 & 2.22 & 1.200 & \\
\hline \multirow[b]{2}{*}{7} & \multirow{2}{*}{$\begin{array}{l}\text { There should be no link between } \\
\text { education and the requirements of } \\
\text { the labour market }\end{array}$} & Natural Science & 43 & 3.12 & 1.051 & \multirow[b]{2}{*}{.945} \\
\hline & & Social Science & 271 & 3.13 & 1.155 & \\
\hline \multirow{2}{*}{8} & \multirow{2}{*}{$\begin{array}{l}\text { My love for learning was the } \\
\text { reason I enrolled at the university } \\
\text { and not to seek a future job }\end{array}$} & Natural Science & 43 & 2.95 & 1.495 & .172 \\
\hline & & Social Science & 271 & 2.64 & 1.369 & \\
\hline
\end{tabular}

Source: Graduate Sales Bootcamp, 2017.

Table 8. Field of study differences and the confidence in university education

\begin{tabular}{|c|c|c|c|c|c|c|}
\hline $\mathbf{S} / \mathbf{N}$ & Perception & $\begin{array}{l}\text { Academic } \\
\text { Profession }\end{array}$ & $\mathbf{N}$ & Mean & SD & $\begin{array}{l}\text { Sig. (2- } \\
\text { tailed) }\end{array}$ \\
\hline \multirow[b]{2}{*}{9} & \multirow{2}{*}{$\begin{array}{l}\text { I prefer to work in the public } \\
\text { sector rather than in the private } \\
\text { sector. }\end{array}$} & Natural Science & 43 & 3.37 & 1.381 & \multirow{2}{*}{.521} \\
\hline & & Social Science & 271 & 3.23 & 1.397 & \\
\hline \multirow{2}{*}{10} & \multirow{2}{*}{$\begin{array}{l}\text { My University education qualifies } \\
\text { me to pursue any future work. }\end{array}$} & Natural Science & 43 & 1.79 & .773 & \multirow{2}{*}{.487} \\
\hline & & Social Science & 271 & 1.91 & 1.059 & \\
\hline \multirow[b]{2}{*}{11} & \multirow{2}{*}{$\begin{array}{l}\text { I am frightened that my university } \\
\text { education has no value on the } \\
\text { labour market. }\end{array}$} & Natural Science & 43 & 3.47 & .767 & \multirow[b]{2}{*}{.897} \\
\hline & & Social Science & 271 & 3.45 & .892 & \\
\hline \multirow[b]{2}{*}{12} & \multirow{2}{*}{$\begin{array}{l}\text { My university education provided } \\
\text { offers me opportunities to } \\
\text { compete for jobs even outside my } \\
\text { country }\end{array}$} & Natural Science & 43 & 1.81 & .664 & \multirow[b]{2}{*}{.647} \\
\hline & & Social Science & 271 & 1.89 & 1.099 & \\
\hline \multirow[b]{2}{*}{13} & \multirow{2}{*}{$\begin{array}{l}\text { I trust that I will quickly find a } \\
\text { Job appropriate to my university } \\
\text { education }\end{array}$} & Natural Science & 43 & 2.40 & 1.275 & \multirow[b]{2}{*}{.838} \\
\hline & & Social Science & 271 & 2.35 & 1.341 & \\
\hline \multirow[b]{2}{*}{14} & \multirow{2}{*}{$\begin{array}{l}\text { My university education offers me } \\
\text { opportunities to compete for jobs } \\
\text { outside of Tanzania. }\end{array}$} & Natural Science & 43 & 1.86 & .743 & \multirow[b]{2}{*}{.437} \\
\hline & & Social Science & 271 & 2.00 & 1.104 & \\
\hline \multirow{2}{*}{15} & \multirow{2}{*}{$\begin{array}{l}\text { My university education qualifies } \\
\text { me to work immediately after } \\
\text { graduation. }\end{array}$} & Natural Science & 43 & 2.00 & 1.024 & \multirow{2}{*}{.234} \\
\hline & & Social Science & 271 & 2.24 & 1.255 & \\
\hline
\end{tabular}

Source: Graduate Sales Bootcamp, 2017.

Table 9. Field of study differences and the relevance of curriculum for the world of work

\begin{tabular}{|c|c|c|c|c|c|c|}
\hline $\mathbf{S} / \mathbf{N}$ & Perception & $\begin{array}{l}\text { Academic } \\
\text { Profession } \\
\end{array}$ & $\mathbf{N}$ & Mean & SD & $\begin{array}{l}\text { Sig. (2- } \\
\text { tailed) }\end{array}$ \\
\hline \multirow{2}{*}{16} & \multirow{2}{*}{$\begin{array}{l}\text { The government has to provide } \\
\text { me with a job appropriate to my } \\
\text { university education. }\end{array}$} & Natural Science & 43 & 3.12 & 1.219 & \multirow{2}{*}{.051} \\
\hline & & Social Science & 271 & 2.71 & 1.277 & \\
\hline \multirow{2}{*}{17} & \multirow{2}{*}{$\begin{array}{l}\text { I've to get intensive training after } \\
\text { graduation }\end{array}$} & Natural Science & 43 & 2.63 & 1.176 & \multirow{2}{*}{.173} \\
\hline & & Social Science & 271 & 2.34 & 1.320 & \\
\hline \multirow{2}{*}{18} & \multirow{2}{*}{$\begin{array}{l}\text { There is no stronger relationship } \\
\text { between what we study and the } \\
\text { requirement of the labour market. }\end{array}$} & Natural Science & 43 & 2.95 & 1.194 & \multirow{2}{*}{.478} \\
\hline & & Social Science & 271 & 2.82 & 1.181 & \\
\hline \multirow[b]{2}{*}{19} & \multirow{2}{*}{$\begin{array}{l}\text { The curriculums should include } \\
\text { more practical aspect that will } \\
\text { better fit our future careers. }\end{array}$} & Natural Science & 43 & 1.60 & .979 & \multirow{2}{*}{.028} \\
\hline & & Social Science & 271 & 1.35 & .659 & \\
\hline
\end{tabular}


Table 9 (cont.)

\begin{tabular}{|c|l|l|c|c|c|c|}
\hline \multirow{2}{*}{20} & $\begin{array}{l}\text { We lack many of the skills we } \\
\text { need for our future and current } \\
\text { careers, even after university } \\
\text { education. }\end{array}$ & Natural Science & 43 & 2.30 & 1.206 & \multirow{2}{*}{.195} \\
\cline { 3 - 6 } 21 & $\begin{array}{l}\text { The curriculum should focus more } \\
\text { on generic skills rather than } \\
\text { content }\end{array}$ & Natural Science & 43 & 1.95 & 1.174 & \multirow{2}{*}{.005} \\
\cline { 2 - 5 } & Social Science & 271 & 1.51 & .930 & 1.130 & \\
\hline
\end{tabular}

Source: Graduate Sales Bootcamp, 2017.

In terms of the employment status of the respondents, differences between two groups are shown in Table 10, Table 11 and Table 12. Employed respondents indicated more belief in the following three items and $\mathrm{p}<0.05$ : Item 12 in Table 11 - My university education provided offers me opportunities to compete for jobs even outside my country, Item 13 in Table 11- I trust that I will quickly find a Job appropriate to my university education and Item 16 in Table 12 - The government has to provide me with a job appropriate to my university education. A more convincing explanation for these findings is that employment prospects are influenced by actual experiences (e.g. embedded in the curriculum or after individuals have assumed professional responsibilities) rather than awareness: Employed graduates in the study may already possess skills that can be transferred from one job to other and also networks. The Inter University Council of East Africa in 2014 estimates that East African graduates on average secure employment within three months (Kessy, 2020). This view differs from Omolo (2010) who states in Kenya it is five years.

Table 10. Employment status differences and the link between university and the world of work

\begin{tabular}{|c|c|c|c|c|c|c|}
\hline $\mathbf{S} / \mathbf{N}$ & Perception & $\begin{array}{c}\text { Employment } \\
\text { status }\end{array}$ & $\mathbf{N}$ & Mean & SD & $\begin{array}{l}\text { Sig. (2- } \\
\text { tailed) }\end{array}$ \\
\hline \multirow{2}{*}{1} & \multirow{2}{*}{$\begin{array}{l}\text { I've good knowledge about the } \\
\text { requirements of future career. }\end{array}$} & Employed & 89 & 1.60 & .734 & \multirow{2}{*}{.985} \\
\hline & & Unemployed & 224 & 1.59 & .781 & \\
\hline \multirow{2}{*}{2} & \multirow{2}{*}{$\begin{array}{l}\text { I've decided which jobs I'll apply } \\
\text { after graduation. }\end{array}$} & Employed & 89 & 2.36 & 1.325 & \multirow{2}{*}{.589} \\
\hline & & Unemployed & 224 & 2.27 & 1.271 & \\
\hline \multirow{2}{*}{3} & \multirow{2}{*}{$\begin{array}{l}\text { I Worry a lot about my future } \\
\text { career. }\end{array}$} & Employed & 89 & 3.13 & 1.089 & \multirow{2}{*}{.262} \\
\hline & & Unemployed & 224 & 2.96 & 1.300 & \\
\hline \multirow{2}{*}{4} & \multirow{2}{*}{$\begin{array}{l}\text { I must get a job that is appropriate } \\
\text { to my academic major. }\end{array}$} & Employed & 89 & 2.89 & 1.265 & \multirow[t]{2}{*}{.173} \\
\hline & & Unemployed & 224 & 2.67 & 1.241 & \\
\hline \multirow{2}{*}{5} & \multirow{2}{*}{$\begin{array}{l}\text { I see a link between academic } \\
\text { excellence and my future work } \\
\text { success. }\end{array}$} & Employed & 89 & 2.09 & 1.145 & \multirow{2}{*}{.511} \\
\hline & & Unemployed & 224 & 2.00 & 1.067 & \\
\hline \multirow[b]{2}{*}{6} & \multirow{2}{*}{$\begin{array}{l}\text { I chose my field of study because } \\
\text { of its strong link to the labour } \\
\text { market. }\end{array}$} & Employed & 89 & 2.24 & 1.138 & \multirow{2}{*}{.949} \\
\hline & & Unemployed & 224 & 2.25 & 1.223 & \\
\hline \multirow{2}{*}{7} & \multirow{2}{*}{$\begin{array}{l}\text { There should be no link between } \\
\text { education and the requirements of } \\
\text { the labour market }\end{array}$} & Employed & 89 & 3.09 & 1.231 & \multirow{2}{*}{.688} \\
\hline & & Unemployed & 224 & 3.15 & 1.105 & \\
\hline \multirow{2}{*}{8} & \multirow{2}{*}{$\begin{array}{l}\text { My love for learning was the } \\
\text { reason I enrolled at the university } \\
\text { and not to seek a future job. }\end{array}$} & Employed & 89 & 2.52 & 1.463 & \multirow{2}{*}{.164} \\
\hline & & Unemployed & 224 & 2.76 & 1.354 & \\
\hline
\end{tabular}

Source: Graduate Sales Bootcamp, 2017.

Table 11. Employment status Differences and the Confidence in university education

\begin{tabular}{|c|l|l|l|l|l|c|}
\hline S/N & \multicolumn{1}{|c|}{ Perception } & $\begin{array}{c}\text { Employment } \\
\text { status }\end{array}$ & $\mathbf{N}$ & Mean & SD & $\begin{array}{c}\text { Sig. (2- } \\
\text { tailed) }\end{array}$ \\
\hline \multirow{2}{*}{9} & $\begin{array}{l}\text { I prefer to work in the public } \\
\text { sector rather than in the private } \\
\text { sector. }\end{array}$ & Employed & 89 & 3.22 & 1.420 & \multirow{2}{*}{.865} \\
\cline { 2 - 8 } & Unemployed & 224 & 3.25 & 1.389 & \\
\hline
\end{tabular}


Table 11 (cont.)

\begin{tabular}{|c|c|c|c|c|c|c|}
\hline \multirow{3}{*}{10} & \multirow{3}{*}{$\begin{array}{l}\text { My University education qualifies } \\
\text { me to pursue any future work. }\end{array}$} & Fmoloud & & & & \multirow{3}{*}{.436} \\
\hline & & Em11pioyed & 89 & 1.97 & 1.030 & \\
\hline & & Unemployed & 224 & 1.87 & 1.020 & \\
\hline \multirow{2}{*}{11} & \multirow{2}{*}{$\begin{array}{l}\text { I am frightened that my university } \\
\text { education has no value on the } \\
\text { labour market. }\end{array}$} & Employed & 89 & 3.46 & .880 & \multirow{2}{*}{.897} \\
\hline & & Unemployed & 224 & 3.45 & .877 & \\
\hline \multirow[b]{2}{*}{12} & \multirow{2}{*}{$\begin{array}{l}\text { My university education provided } \\
\text { offers me opportunities to } \\
\text { compete for jobs even outside my } \\
\text { country }\end{array}$} & Employed & 89 & 2.15 & 1.230 & \multirow[b]{2}{*}{.005} \\
\hline & & Unemployed & 224 & 1.78 & .954 & \\
\hline \multirow{2}{*}{13} & \multirow{2}{*}{$\begin{array}{l}\text { I trust that I will quickly find a } \\
\text { Job appropriate to my university } \\
\text { education }\end{array}$} & Employed & 89 & 2.60 & 1.467 & \multirow{2}{*}{.044} \\
\hline & & Unemployed & 224 & 2.26 & 1.265 & \\
\hline \multirow{2}{*}{14} & \multirow{2}{*}{$\begin{array}{l}\text { My university education offers me } \\
\text { opportunities to compete for jobs } \\
\text { outside of Tanzania. }\end{array}$} & Employed & 89 & 2.12 & 1.185 & \multirow{2}{*}{.134} \\
\hline & & Unemployed & 224 & 1.92 & 1.006 & \\
\hline \multirow{2}{*}{15} & \multirow{2}{*}{$\begin{array}{l}\text { My university education qualifies } \\
\text { me to work immediately after } \\
\text { graduation. }\end{array}$} & Employed & 89 & 2.11 & 1.182 & \multirow{2}{*}{.388} \\
\hline & & Unemployed & 224 & 2.25 & 1.248 & \\
\hline
\end{tabular}

Source: Graduate Sales Bootcamp, 2017.

Table 12. Employment Status Differences and the relevance of curriculum for the world of work

\begin{tabular}{|c|c|c|c|c|c|c|}
\hline $\mathbf{S} / \mathbf{N}$ & Perception & $\begin{array}{c}\text { Employment } \\
\text { status }\end{array}$ & $\mathbf{N}$ & Mean & SD & $\begin{array}{l}\text { Sig. (2- } \\
\text { tailed) }\end{array}$ \\
\hline \multirow{2}{*}{16} & \multirow{2}{*}{$\begin{array}{l}\text { The government has to provide } \\
\text { me with a job appropriate to my } \\
\text { university education. }\end{array}$} & Employed & 89 & 2.99 & 1.220 & \multirow{2}{*}{.049} \\
\hline & & Unemployed & 224 & 2.67 & 1.290 & \\
\hline \multirow{2}{*}{17} & \multirow{2}{*}{$\begin{array}{l}\text { I've to get intensive training after } \\
\text { graduation }\end{array}$} & Employed & 89 & 2.24 & 1.225 & \multirow{2}{*}{.239} \\
\hline & & Unemployed & 224 & 2.43 & 1.334 & \\
\hline \multirow{2}{*}{18} & \multirow{2}{*}{$\begin{array}{l}\text { There is no stronger relationship } \\
\text { between what we study and the } \\
\text { requirement of the labour market. }\end{array}$} & Employed & 89 & 2.74 & 1.183 & \multirow{2}{*}{.352} \\
\hline & & Unemployed & 224 & 2.88 & 1.179 & \\
\hline \multirow{2}{*}{19} & \multirow{2}{*}{$\begin{array}{l}\text { The curriculums should include } \\
\text { more practical aspect that will } \\
\text { better fit our future careers. }\end{array}$} & Employed & 89 & 1.34 & .656 & \multirow{2}{*}{.472} \\
\hline & & Unemployed & 224 & 1.40 & .739 & \\
\hline \multirow[b]{2}{*}{20} & \multirow{2}{*}{$\begin{array}{l}\text { We lack many of the skills we } \\
\text { need for our future and current } \\
\text { careers, even after university } \\
\text { education. }\end{array}$} & Employed & 89 & 2.00 & 1.206 & \multirow[b]{2}{*}{.350} \\
\hline & & Unemployed & 224 & 2.13 & 1.116 & \\
\hline \multirow{2}{*}{21} & \multirow{2}{*}{$\begin{array}{l}\text { The curriculum should focus more } \\
\text { on generic skills rather than } \\
\text { content }\end{array}$} & Employed & 89 & 1.67 & 1.250 & \multirow{2}{*}{.202} \\
\hline & & Unemployed & 224 & 1.52 & .842 & \\
\hline
\end{tabular}

Source: Graduate Sales Bootcamp, 2017.

\section{Concluding Remarks}

Based on the survey results and in the context of the study's agenda, findings have shown a different perspective regarding the quality and employability of Tanzanian graduates as well as the role of universities as drivers for innovation. Graduates were appreciative of their university education and were confident that they can meet the requirements of the labour market. This is mainly because they value the role of higher education credentials for graduate employability or worded differently employers' value degrees and reward more educated workers. However, they acknowledged their theoretical knowledge, skills and competencies have little value until they can apply them for practical purposes. The implication is that their participation in society and 
ability to cope with changes brought about by innovation will be limited, including becoming successful business owners.

While many universities around the globe have implemented various initiatives and teaching and learning methods to embed the most in-demand skills into their degree programmes, Tanzanian universities continue to focus on promoting discipline-specific content knowledge at the expense of generic skills required in the workplace which would have enhance graduates' employment prospects. Where a weak education system collides with economic, technological, demographic, and geopolitical trends, the risks of graduate unemployment, poverty, inequality, and instability are at their greatest. The risks of producing graduates who cannot drive the country's development are also significant.

Tanzania had projected to become a middle income economy by 2025 (URT,2000), but has now achieved the goal five years earlier on $1^{\text {st }}$ July 2020. The lessons from upper-middle and highincome economies suggest: in order to build world-class education systems and enhance employment prospects for graduates, universities should seriously commit to reducing the gap between what university students and graduates want, demand, and believe they have a right to, and what they can actually access and receive. But to do it well, universities should strive to deploy new or improved educational technology tools, instructional methods, curricula, assessment approaches - involving entrepreneurs, industry and government.

\section{Acknowledgments}

I would like to gratefully acknowledge the participation of graduates whose voluntary contribution to fill in the questionnaire prior to attending the Graduate Sales Bootcamp in 2017 made this research possible. Thanks also to Dioni Sabi and Ombeni Kaluse for their research assistance in cleaning the database and generating the statistical tables.

\section{References}

1. Al-Harthi, H.K., 2011. University student perceptions of the relationship between university education and the labour market in Egypt and Oman. Prospects 41, pp. 535-551. https://doi.org/10.1007/s11125-011-9216-4.

2. Aubert, J.E., Chen, D., Kim, R., Kuznetzov., Larsen K., Theus, F. and White J., 2010. Innovation policy: A guide for developing countries. Washington, DC: The World Bank.

3. Bastos, C.A and Rebois, R.R., 2011. Review and evaluation of the performance of Tanzania's higher education institutions in science, technology and innovation. Dar es Salaam: Tanzania Government \& UNESCO.

4. Beaumont, E., Gedye, S. and Richardson, S., 2016. 'Am I employable?’: Understanding students' employability confidence and their perceived barriers to gaining employment. Journal of Hospitality, Leisure, Sport \& Tourism Education, 19: pp. 1-9.

5. Becker, G.S., 1994. Human capital revisited. In Human Capital: A Theoretical and Empirical Analysis with Special Reference to Education.3rd Edition. pp. 15-28. Chicago: The University of Chicago Press.

6. Borrás, S. and Edquist, C., 2015. Education, training and skills in innovation policy. Science and Public Policy, 42(2), pp.215-227.

7. Bourdieu , P., 1986. The forms of capital. In J. Richardson (Ed.), Handbook of Theory and Research for the Sociology of Education (241-258). Westport, CT: Greenwood.

8. Bowles, S. and Gintis, H., 1975. The problem with human capital theory - A Marxian critique. The American Economic Review, 65(2), pp.74-82.

9. Brown, P., 2003. The opportunity trap: education and employment in a global economy. European Educational Research Journal, 2.1, pp.141-179.

10. Brown, P., Lauder, H. and Ashton, D., 2010. The Global Auction: The Broken Promises of Education, Jobs and Rewards. New York: Oxford University Press.

11. Calestous, J., 2016. Education, Research, and Innovation in Africa: Forging Strategic Linkages for Economic Transformation. Discussion Paper, 2016-01, Science, Technology, and Globalization Project, Belfer Center. 
12. Cobo, C., 2013. Skills for innovation: envisioning an education that prepares for the changing world, The Curriculum Journal, 24(1),pp.67-85, DOI: 10.1080/09585176.2012.744330

13. Coleman, J., 1990. Foundations of Social Theory. Cambridge, MA: Harvard.

14. Collins, R., 1979. The credential society an historical sociology of education and stratification. New York: Academic Press.

15. Curtin, P., Stanwick, J. and Beddie, F., 2011. Fostering enterprise: the innovation and skills nexus research readings, NCVER, Adelaide.

16. Dolton, P.J., Greenaway, D. and Vignoles, A., 1997. 'Whither Higher Education? 'An Economic Perspective for the Dearing Committee of Inquiry. The Economic Journal, 107.442, pp.710-726.

17. Dominic, T. and Fulgence, K., 2019. Gender Differences in Enhancing Students' Employability Skills. ORSEA Journal 9, pp.57-71.

18. Dunga, H., 2016. An explanatory study of the variation in unemployment length of graduates of different degree programs. International Business and Economics Research Journal, 15(2), pp.69- 78

19. Hanson, S. and Overton, T., 2010b. Skills required by new forensic science graduates and their development in degree programmes. Hull, UK: Higher Education Academy UK Physical Sciences Centre.

20. Hanson, S. and Overton, T., 2010a. Skills required by new chemistry graduates and their development in degree programmes. Hull, UK: Higher Education Academy UK Physical Sciences Centre.

21. Hanson, S. and Overton, T., 2010c. Skills required by new physics graduates and their development in degree programmes. Hull, UK: Higher Education Academy UK Physical Sciences Centre.

22. Hill, M., Overton, T., Thompson, C., Kitson, R., and Coppo, P., 2019. Undergraduate recognition of curriculum-related skill development and the skills employers are seeking. Chemistry Education Research and Practice 20(1), pp.68-84.

23. International Labour Office, 2012a. Africa's response to the youth employment crisis: Regional report. Geneva: International Labour Office. Economic Commission for Africa.

24. International Labour Office, 2012b. Global employment trends for youth 2012. Geneva: International Labour Office.

25. International Labour Organization (ILO), 2020. Global Employment Trends for Youth: Special issue on the impact of the global economic crisis on youth. ILO: Geneva.

26. Katundu, M.A. and Gabagambi, D.M., 2016. Barriers to Business Start-up among Tanzanian University Graduates: Evidence from the University of Dar-es-salaam. Global Business Review, 17(1), pp.16-37. https://doi.org/10.1177/0972150915610667.

27. Kessy, A., 2020. Higher education and prospects of graduates' Employability in Tanzania, Journal of Education and Practice 11(9), pp.177-187.

28. Lynch, D., 2017. Self evaluation: Building Student Self-awareness and Competence. Proceedings of the Canadian Engineering Education Association (CEEA)17. Paper 131. University of Toronto: Toronto.

29. Mirondo, R., 2017. Graduate skills wanting. Available at http://www.thecitizen.co.tz/News/Business/Graduates--skills-wanting--TPSF/1840414-3824624gcffb9/index.html. [Accessed on $25^{\text {th }}$ June 2020].

30. Mkude, D., Cooksey, B., and Levey, L., 2003. Higher education in Tanzania: A case study. Oxford: James Currey.

31. Mori, N., 2014) Women's entrepreneurship development in Tanzania: insights and recommendations Geneva: ILO.

32. Mpehongwa, G. and Moshi, S., 2014. Career choices of university students in Tanzania and their implications for Vision 2025. International Journal of Humanities and Social Science.4(5), pp.260266.

33. Mutalemwa, D., 2020. Available at: www.darlenemutalemwa.com. [Accessed $26^{\text {th }}$ January 2020]

34. Naong, M., 2011. Promotion of entrepreneurship education: A remedy to graduates and youth unemployment. Journal of Social Science, 28(3), pp.181-189.

35. National Bureau of Statistics, 2017. Women and men in Tanzania: facts and Figures. Available at: https://www.nbs.go.tz/nbs/takwimu/WomenAndMen/women_and_men_booklet.pdf. [Accessed $26^{\text {th }}$ July 2020].

36. OECD, 2011. Skills for innovation and research. OECD: Paris https://doi.org/10.1787/9789264097490-en [Accessed 1st May 2020].

37. OECD, 2017. Executive summary, in education at glance 2017: OECD Indicators, OECD Publishing, Paris. DOI: https://doi.org/10.1787/eag-2017-5-en 
38. OECD, 2017. Education at a glance 2017: OECD indicators, OECD Publishing, Paris, https://doi.org/10.1787/eag-2017-en. [Accessed 1st May 2020].

39. Omolo, O.J., 2010. The dynamics and trends of employment in Kenya, IEA Research Paper Series, No. 1/2010, Nairobi: Institute of Economic Affairs.

40. Page, J., 2016) Industry in Tanzania - Performance, prospects, and public policy. Working Paper 2016/5. Helsinki: WIDER.

41. Paterson, R., 2017. Lecturer and student perceptions of employability skills at a transnational university. Qualitative research in education, 6(3), pp.241-275. https:// doi.org/10.17583/qre.2017.2583.

42. Policy Forum, 2018. The state of youth empowerment and financial inclusion in Tanzania. Available at: https://www.policyforum-tz.org/sites/default/files/brief\%204.19.pdf [Accessed on 14 ${ }^{\text {th }}$ August 2020].

43. Poon, J., 2016. An investigation of characteristics affecting employment outcomes and patterns of real estate graduates", Property Management, 34(3), pp. 180-198. https://doi.org/10.1108/PM-052015-0024.

44. Qenani, E., MacDougall, N., and Sexton C., 2014. An empirical study of self-perceived employability: Improving the prospects for student employment success in an uncertain environment. Active Learning in Higher Education. 15(3), pp.199-213.

45. Saher, U. and Ch, H. A., 2019. A comparison of self-perceived employability of graduates from public and private universities of Punjab, Bulletin of Education and Research 41(1), pp.119-130.

46. Sarkar, M., Overton, T., Thompson, C. and Rayner, G., 2016. Graduate Employability: Views of Recent Science Graduates and Employers, Int. J. Innov. Sci. Math. Educ., 24(3), pp. 31-48.

47. Shuma, C.J., 2017. Enhancing employability skills among higher learning students through career guidance and counseling: Experience from the University of Dodoma and Saint John's University of Tanzania, Dodoma: University of Dodoma.

48. Simson, R., 2016. Patronage or meritocracy? Public sector employment in postcolonial Kenya, Tanzania and Uganda. African Economic History Network Working Paper Series, No. 26. Retrieved from https://www.aehnetwork.org/wp-content/uploads/2016/06/AEHN-WP26.pdf

49. Smith, A, Courvisanos, J., Tuck,J, and McEachern, S., 2012. Building the capacity to innovate: The role of human capital. Adelaide, Australia: National Centre for Vocational Education Research.

50. Stanwick, J., 2011. Innovation: its links with productivity and skill development. At a Glance. Adelaide, SA: NCVER.

51. TCU, 2018. Higher education students admissions, enrolment and graduations Statistics 2012/132017/18 Available at: https://www.tcu.go.tz/sites/default/files/Admission\%20and\%20Graduation\%20Statistics.pdf [Accessed 26 ${ }^{\text {th }}$ January 2020]

52. Toner, P., 2011. Workforce skills and innovation: An overview of major themes in the literature, OECD Education Working Papers, 55. Paris: OECD.

53. Unido \& United Republic Of Tanzania, 2012. Tanzania industrial competitiveness report 2012. Dares-Salaam: UNIDO and URT.

54. United Republic of Tanzania (URT), 2018. Education sector development plan (2016/17 - 2020/21) Tanzania Mainland, Ministry of Education.

55. URT, 2017. National internship guidelines. Dodoma: Prime Minister Office.

56. URT, 2000. National development vision 2025, Dar-es-Salaam: Ministry of Finance and Planning.

57. URT, 2016. National five years development plan 2016/17-2020/21, Dar-es-Salaam: Ministry of Finance and Planning, Dodoma, Tanzania.

58. Van der Wal, Z. and Oosterbaan, A., 2013. Government or Business? Identifying determinants of MPA and MBA students career preferences.Public Personnel Management 42 (2), pp. 239-258.

59. Wakkee, I.,Hoestenberghe, K. and Mwasalwiba, E., 2017. Capability, social capital and opportunity driven graduate entrepreneurship in Tanzania, Journal of Small Business and Enterprise Development (6), pp 83-88.

60. Wildavsky, B., Kelly, A. and Carey, K. (Eds.), 2012. Reinventing higher education: The promise of innovation, Cambridge, MA: Harvard Education Press.

61. World Bank, 2020. Doing Business 2020. Washington DC: World Bank.

62. World Bank Group, 2014. Tanzania: Productive Jobs Wanted. Washington DC: World Bank.

63. World Economic Forum, 2018. The future of jobs report 2018. Geneva: World Economic Forum.

64. Yorke, M., 2006. Employability in higher Education: What it is - What it is not. Vol.1. York: Higher Education Academy. 